\title{
Effects of adiCox®AP and monensin on production parameters and quality of meat of slow-growing Hubbard JA 957 broiler chickens
}

\author{
M. Łukasiewicz ${ }^{1 \#}$, M. Michalczuk ${ }^{1}$, D. Pietrzak $^{2}$ \& J. Niemiec ${ }^{1}$ \\ ${ }^{1}$ Faculty of Animal Sciences, Warsaw University of Life Sciences (SGGW), Warsaw, Poland \\ ${ }^{2}$ Faculty of Food Technology, Warsaw University of Life Sciences (SGGW), Warsaw, Poland
}

(Received 18 July 2013; Accepted 2 April 2014; First published online 30 May 2014)

\begin{abstract}
Copyright resides with the authors in terms of the Creative Commons Attribution 2.5 South African Licence.
See: http://creativecommons.org/licenses/by/2.5/za

Condition of use: The user may copy, distribute, transmit and adapt the work, but must recognise the authors and the South African Journal of Animal Science.
\end{abstract}

\begin{abstract}
This experiment was conducted with 480 Hubbard JA 957 one-day-old broiler chicks to determine the effects of adiCox®AP, a plant coccidiostat, and monensin on production parameters and meat quality. The birds were randomly allocated to three experimental diets: $(A)$ with the plant coccidiostat adiCox®AP; (M) with monensin, an ionophore coccidiostat; and (C) the control group without coccidiostats. The birds were reared on litter until 63 days of age. The bodyweight of chicks was recorded at the ages of 1, 12, 24, 42 and 63 days. The feed conversion ratio (FCR) and mortality ratio were calculated. There were no significant differences in bodyweight and FCR of birds tested across the experimental groups. In particular feeding groups, the mortality rate ranged from $2.60 \%$ to $4.33 \%$, with the lowest number of deaths being noted in the groups receiving the plant coccidiostat $(2.6 \%)$, whereas the highest mortality rate was recorded in the control group. The type of coccidiostat had no significant effect on the chemical composition of breast muscles. However, the leg muscles of the control chickens were characterized by a significantly higher content of protein (19.4\%), compared with the groups receiving coccidiostats in the feed mixtures $(19.1 \%$ in $\mathrm{A}$ and $18.6 \%$ in $\mathrm{M})$. The plant coccidiostat effected a higher water-holding capacity (52.2\%) and a lower cooking loss (6.9\%) in the leg muscles of the birds. The administration of the plant feed supplement adiCox®AP significantly decreased the mortality rate of broiler chickens without compromising other production traits. The results also show that the applied plant preparation is an excellent alternative to antibiotic growth stimulants.
\end{abstract}

Keywords: Coccidiostats, meat quality, poultry

\# Corresponding author: monika_lukasiewicz@sggw.pl

\section{Introduction}

Meat and food products of animal origin are main elements of the human diet. One of the most valuable meat products, from inter alia the dietetic point of view, is poultry meat. Coccidiostats are substances that have been used for years against coccidiosis, a disease induced by protozoa of the genus Eimeria. Coccidiosis causes significant economic losses in the poultry industry, especially among broiler chickens. Coccidiostats are divided into two groups in terms of the mechanism of their action: ionophore and chemical. Ionophore coccidiostats are produced via fermentation of a few strains of Streptomyces spp. and Actinomadura spp. bacteria. They disturb the transport of monovalent and divalent ions through the cellular membrane of a parasite. In turn, chemical coccidiostats are synthesized chemically. They block the developmental cycle of Eimeria, by influencing selected species of the protozoon.

In modern intensive poultry production, the control of coccidiosis is based on chemoprophylaxis that includes, most of all, routine supplementation of coccidiostats in feed with account given to the waiting period, while immunoprophylaxis (vaccinations) is applied to a lesser extent. Issues that are addressed increasingly these days are the role of coccidiostats in feed and the risk posed to consumers' health by their usage. The perception is that residues of some coccidiostats may remain in the muscles of birds, which raises concern among consumers (Olejnik et al., 2009). As a result, on 1 January 2008, the European Commission (EC) presented a report on the withdrawal of coccidiostats from feed mixtures. Furthermore, Regulation (EC) No 1831/2003 stated explicitly that the ban on the prophylactic use of coccidiostats in feed was to be valid from 2013 (Anonymous, 2003). In view of this, a tangible interest emerges in the development of alternative methods for coccidiosis prevention. Many studies are currently under way that 
use plants and plant products with the potential to reduce the occurrence of Eimerii in gastrointestinal microflora (Chandrakesan et al., 2009; Abbas et al., 2010; Lee et al., 2010; Haq et al., 2011).

Nevertheless, the cheapest and the most effective method in coccidiosis prophylaxis is the administration of coccidiostats in feed (Olejnik et al., 2007). Their improper use, however, has led to the development of resistant strains of the Eimeria genus (Ruff \& Danforth, 1996). An ionophore coccidiostat that is most often reported to remain in chicken tissues is lasalocid, the half-life of which is ca. 34 hours (Kennedy et al., 1995). Hence, there is an urgent need to continue studies in order to elaborate effective substitutes for chemical coccidiostats.

The feed supplement adiCox®AP is available on the Polish market and, according to the manufacturer, displays high availability, as well as evident activity and optimal physicochemical parameters. It is a composition of natural compounds (phytoncides and phytoalexins) that activate and support animals' immunity against bacterial infections and protozoan infestations. It has an antiprotozoan function, acting mainly on Eimeria (Coccidiomorpha), flagellates (Mastigophora), ciliates (Ciliata) and amoebae (Amoebozoa). In addition, it supports the mechanisms of elimination of anaerobic bacteria (e.g. Bacteroides and Clostridium genera) and Mycoplasma (Różański \& Drymel, 2010). The objective of this experiment was to determine the effect of adiCox®AP, a plant coccidiostat, and monensin, an ionophore coccidiostat, on production parameters and quality of meat of slow-growing Hubbard JA 957 broiler chickens.

\section{Material and Methods}

The experiment was carried out with 480 slow-growing one-day-old Hubbard JA 957 broiler chickens, reared to 63 days of age in typical husbandry conditions on cut straw litter at 15 birds per $\mathrm{m}^{2}$. A three-stage feeding programme was applied throughout the rearing period (Table 1). Chicks were allocated at random to three experimental groups of 160 chicks per treatment, in four replications $\times 40$ chicks. The experimental treatments were Treatment C (control); Treatment A (a plant coccidiostat adiCox ${ }^{\circ} A P$ at $50 \mathrm{~g} / \mathrm{t}$ (ingredients: hydrogenated palm oil, dry pepper fruit, white mustard seed; sensory additives: herbs $98 \%$, thymol: $0.5 \%$ ), (Adifeed, Poland), and Treatment M (an ionophore coccidiostat monensin, at $25 \mathrm{~g} / \mathrm{t}$ ) (Ekoplon, Poland).

Table 1 Dietary ingredients and nutrient composition of experimental diets

\begin{tabular}{|c|c|c|c|}
\hline $\begin{array}{l}\text { Ingredient composition } \\
(\%)^{1}\end{array}$ & Starter & Grower & Finisher \\
\hline Wheat (11\%) & 50.3 & 53.1 & 59.4 \\
\hline Soybean meal (HiPro 46\%) & 31.7 & 29.2 & 23.2 \\
\hline Maize $(8.5 \%)$ & 10.0 & 10.0 & 10.0 \\
\hline Premix & 4.00 & 4.00 & 4.00 \\
\hline Dicalcium phosphate & 1.48 & 0.97 & 0.65 \\
\hline Soybean oil & 1.44 & 1.86 & 1.95 \\
\hline $\mathrm{NaCl}$ & 0.33 & 0.33 & 0.34 \\
\hline Methionine & 0.33 & 0.24 & 0.20 \\
\hline Limestone & 0.14 & 0.18 & 0.00 \\
\hline Phytase & 0.10 & 0.10 & 0.10 \\
\hline Xylanase & 0.10 & 0.10 & 0.10 \\
\hline Lysine HCL & 0.08 & 0.00 & 0.03 \\
\hline \multicolumn{4}{|l|}{ Nutrient composition } \\
\hline Metabolizable energy (MJ/kg) & 11.9 & 12.1 & 12.4 \\
\hline Crude protein $(\mathrm{g} / \mathrm{kg})$ & 209.8 & 200.0 & 180.0 \\
\hline Crude fibre $(\mathrm{g} / \mathrm{kg})$ & 28.8 & 28.8 & 29.1 \\
\hline Crude fat $(\mathrm{g} / \mathrm{kg})$ & 35.1 & 39.4 & 40.6 \\
\hline Lysine (g/kg) & 11.7 & 10.4 & 9.0 \\
\hline Methionine + cysteine $(\mathrm{g} / \mathrm{kg})$ & 9.8 & 8.8 & 7.8 \\
\hline Calcium, total $(\mathrm{g} / \mathrm{kg})$ & 10.0 & 9.0 & 7.5 \\
\hline Phosphorus, available (g/kg) & 4.8 & 4.0 & 3.5 \\
\hline
\end{tabular}


During the rearing period the chickens received a starter ( 0 to 21 days), grower ( 22 to 55 days) and finisher (56 to 63 days) diet. The chicks from the control group (C) did not receive a coccidiostat in the diet and were not vaccinated against coccidiosis. Starting from the first week, weekly measurements were taken of husbandry conditions in the rearing facility, and samples of faeces were collected to monitor the presence of coccidia. In-house temperature, air relative humidity and concentration of gases $\left(\mathrm{CO}_{2}, \mathrm{NH}_{3}\right.$ and $\left.\mathrm{H}_{2} \mathrm{~S}\right)$ were measured. Bodyweights of chicks were measured at 1, 12, 24, 42 and 63 days of age. At day 63 of rearing, 12 cocks and 12 hens were selected from each group with bodyweights similar to the mean body weight of the group. These birds were slaughtered in a poultry abattoir and the carcasses were chilled for $12 \mathrm{~h}$ at $4{ }^{\circ} \mathrm{C}$. Carcass analyses were carried out and samples of breast muscles, leg muscles and abdominal fat were collected for chemical analyses.

Feed conversion ratio (FCR) (feed intake per unit bodyweight gain) of chickens and their mortality rates were calculated. Furthermore, $24 \mathrm{~h}$ post slaughter, samples of breast and leg muscles were analysed for $\mathrm{pH}_{24}$ with an Elmetron CP-411 $\mathrm{pH}$-meter with a combined electrode (PN ISO, 1990) water-holding capacity (WHC) with a modified blotting-paper method (Mitek \& Słowiński, 2006), cooking loss (Wierbicki et al., 1962) and proximate chemical composition (water, protein, fat and ash) using standard methods (AOAC, 1995). Samples of the abdominal fat of chickens were assayed for fatty acid profile according to PN-EN ISO 5509 (2001). In order to determine oxidative changes, the TBARS index (Shahidi, 1990) was assayed on abdominal fat $72 \mathrm{~h}$ after the chickens were slaughtered, seven days after samples storage in chill conditions $\left(4-6^{\circ} \mathrm{C}\right)$ and 56 days after samples storage in frozen conditions $\left(-18^{\circ} \mathrm{C}\right)$.

Results were tested with the analysis of variance. Computations were made with the least square method, using the statistical software SPSS 19.0 PL for Windows (SPSS, 2010, Inc., Chicago, IL, USA). Treatment effects were considered significant at $P \leq 0.01$ or $P \leq 0.05$. All data were expressed as mean values with pooled standard errors.

\section{Results}

Effects of experimental diets on production and slaughter parameters are collated in Tables 2 and 3 , respectively. The production results confirmed the efficacy of the plant coccidiostat. High bodyweight (3582 g) on day 63 was noted in the group of birds receiving the plant coccidiostat adiCox®AP in their diet. The FCR in the experimental groups of chickens was similar to that in the control group. Yet, a tendency towards a higher FCR was observed in Group A, that is, in birds characterized by the highest bodyweight at the end of the rearing period. The statistical analysis of results demonstrated differences $(P \leq 0.05)$ in mortality rate. In the experiment, the mortality rate ranged from $2.6 \%$ to $4.3 \%$. However, the lowest number of deaths was noted in the chickens receiving the plant coccidiostat (2.6\%), and the highest in the control group (Table 2). Coccidiosis was found to have no impact on the mortality of the birds. Based on findings of necropsy on dead birds and observation of culled individuals, it was established that until day 7 the losses were due to omphalitis. Between weeks 2 and 9, pulmonary hyperaemia, exudative diathesis and sudden death syndrome (SDS) were recorded most commonly. The culled birds had deformed limbs, neck paralysis and crop obstructions.

Table 2 Growth performance of broiler chickens receiving diets with or without coccidiostats during the rearing period (age 63 days)

\begin{tabular}{|c|c|c|c|}
\hline Groups & Bodyweight, g & Mortality, \% & FCR (kg/kg gain) \\
\hline C & 3543 & $4.33^{\mathrm{a}}$ & 2.01 \\
\hline M & 3526 & $3.16^{\mathrm{b}}$ & 2.00 \\
\hline A & 3582 & $2.60^{\mathrm{b}}$ & 2.22 \\
\hline SEM & 145.6 & 1.10 & 0.70 \\
\hline
\end{tabular}

The application of different coccidiostats in diets for chickens reared until 63 days of life had no significant effect on dressing percentage or on breast and leg muscles content in carcasses. For the analysed parameters, no significant differences were determined in the content of abdominal fat in carcass - 
the highest content of this fat was noted in the group receiving the ionophore coccidiostat in their diet, whereas the lowest was in the control group (Table 3). In terms of giblet content in carcasses, significant $(P$ $\leq 0.05$ ) differences were reported between experimental groups only in the percentage content of gizzard. Similar results were achieved by (Pelicia et al., 2004), who used slow-growing birds reared until 85 days of life and fed probiotics and prebiotics with the addition of coccidiostats.

Table 3 Carcass composition (\% of body weight) of broiler chickens receiving diets with or without coccidiostats during the rearing period

\begin{tabular}{lccccccc}
\hline Groups & $\begin{array}{c}\text { Dressing } \\
\text { percentage }\end{array}$ & $\begin{array}{c}\text { Breast } \\
\text { muscles }\end{array}$ & $\begin{array}{c}\text { Leg } \\
\text { muscles }\end{array}$ & Gizzard & Heart & Liver & $\begin{array}{c}\text { Abdominal } \\
\text { fat }\end{array}$ \\
\hline C & 72.2 & 23.25 & 21.43 & $0.85^{\mathrm{b}}$ & 0.51 & 2.27 & 1.97 \\
M & 72.2 & 22.77 & 20.73 & $0.97^{\mathrm{a}}$ & 0.50 & 2.46 & 2.72 \\
A & 73.2 & 23.67 & 20.70 & $0.81^{\mathrm{b}}$ & 0.51 & 2.36 & 2.42 \\
SEM & 0.60 & 0.40 & 0.50 & 0.04 & 0.02 & 0.20 & 0.40 \\
& & & & & & &
\end{tabular}

Mean values in the same column with different superscripts $(a, b)$ differ significantly $(P \leq 0.05)$.

C: control; M: monensin (25 g/t); A: adiCox®AP (50 g/t).

SEM: standard error of mean.

The type of coccidiostat had no significant effect on the chemical composition of breast muscles (Table 4). In turn, leg muscles of the control chickens were characterized by a significantly $(P \leq 0.01)$ higher content of protein (19.4\%), compared with the groups receiving coccidiostats in their feed mixtures: $19.1 \%$ for treatment $\mathrm{A}$ and $\mathbf{1 8 . 6 \%}$ in treatment $\mathrm{B}$. The addition of coccidiostats to feed mixtures caused a significant decrease in cooking loss during thermal treatment of breast muscles. The natural coccidiostat effected a higher water-holding capacity (52.2\%) and a lower cooking loss (6.9\%) in leg muscles of the birds (Table 5). Significant $(P \leq 0.05)$ differences were observed in the contents of fatty acids in the intramuscular fat of breast muscles (for saturated fatty acids (SFA) and monounsaturated fatty acids (MUFA)) and in abdominal fat (SFA). The highest content of SFAs was observed in Group M, and these values were confirmed statistically (Table 6).

Table 4 Chemical composition (\%) of meat from chickens that received diets with or without coccidiostats during the rearing period

\begin{tabular}{lcccccccc}
\hline \multirow{2}{*}{ Groups } & \multicolumn{2}{c}{ Water } & \multicolumn{2}{c}{ Protein } & \multicolumn{2}{c}{ Fat } & \multicolumn{3}{c}{ Ash } \\
\cline { 2 - 9 } & BM & LM & BM & LM & BM & LM & BM & LM \\
\hline C & 74.3 & 72.0 & 23.1 & $19.4^{\mathrm{a}}$ & 1.00 & 7.15 & 1.20 & 1.08 \\
M & 74.7 & 73.2 & 23.0 & $18.7^{\mathrm{b}}$ & 0.80 & 6.80 & 1.13 & 1.00 \\
A & 74.3 & 72.7 & 23.4 & $19.2^{\mathrm{b}}$ & 0.85 & 6.78 & 1.15 & 1.03 \\
SEM & 0.10 & 0.53 & 0.13 & 0.10 & 0.11 & 0.54 & 0.02 & 0.03 \\
& & & & & & & &
\end{tabular}

BM: breast muscles; LM: leg muscles (thigh + shank muscles).

Mean values in the same column with different superscripts $(a, b)$ differ significantly $(P \leq 0.05)$.

C: control; M: monensin (25 g/t); A: adiCox®AP (50 g/t).

SEM: standard error of mean. 
Table 5 Physicochemical traits of meat from chickens that received diets with or without coccidiostats during the rearing period

\begin{tabular}{lcccccc}
\hline \multirow{2}{*}{ Groups } & \multicolumn{2}{c}{ pH24 } & \multicolumn{2}{c}{ Water absorption (\%) } & \multicolumn{2}{c}{ Thermal drip (\%) } \\
\cline { 2 - 7 } & BM & LM & BM & LM & BM & LM \\
\hline C & 5.79 & 6.27 & 22.58 & $39.48^{\mathrm{b}}$ & 3.55 & $10.28^{\mathrm{b}}$ \\
M & 5.79 & 6.26 & 19.43 & $37.85^{\mathrm{b}}$ & 3.18 & $10.33^{\mathrm{a}}$ \\
A & 5.85 & 6.39 & 20.90 & $52.25^{\mathrm{a}}$ & 3.05 & $6.98^{\mathrm{b}}$ \\
SEM & 0.02 & 0.03 & 1.64 & 2.64 & 0.12 & 0.82 \\
& & & & & &
\end{tabular}

BM: breast muscles; LM: leg muscles (thigh + shank muscles).

Mean values in the same column with different superscripts $(a, b)$ differ significantly $(P \leq 0.05)$.

C: control; M: monensin (25 g/t); A: adiCox®AP (50 g/t).

SEM: standard error of mean.

Table 6 Fatty acid composition of the abdominal fat and meat (\% total fatty acids) from chickens receiving diets with or without coccidiostats during the rearing period

\begin{tabular}{cccccc}
\hline Groups & SFA & MUFA & PUFA & PUFA (n-3) & PUFA (n-6) \\
\hline Breast muscles & & & & & \\
C & 30.0 & 42.9 & 25.8 & 2.49 & 22.35 \\
M & 30.8 & 44.2 & 24.8 & 2.47 & 22.30 \\
A & 30.7 & 44.7 & 24.7 & 2.46 & 22.19 \\
SEM & 0.462 & 0.845 & 0.839 & 0.073 & 0.765 \\
Thigh muscles & & & & & \\
C & 29.5 & 43.9 & 25.9 & 2.34 & 23.59 \\
M & 28.9 & 43.8 & 25.0 & 2.29 & 22.68 \\
A & 28.8 & 43.9 & 25.0 & 2.25 & 22.71 \\
SEM & 0.485 & 0.882 & 0.947 & 0.088 & 0.926 \\
Abdominal fat & & & & & \\
C & 27.8 & 44.0 & 25.9 & 2.31 & 23.63 \\
M & 26.0 & 44.8 & 26.9 & 2.41 & 24.50 \\
A & 24.9 & 46.0 & 27.0 & 2.18 & 24.77 \\
SEM & 0.753 & 1.605 & 1.399 & 0.143 & 1.405
\end{tabular}

SFA: saturated fatty acids, C12:0 (lauric acid); C13:0 (tridecylic acid); C14:0 (myristic acid); C16:0 (palmitic acid); C17:0 (margaric acid); C18:0 (stearic acid); C20:0 (arachidic acid); C22:0 (behenic acid);

MUFA: monounsaturated fatty acids, C14:1 (myristoleic acid); C16:1 (palmitoleic acid); C17:1 (ginkgolic acid); C18:1

(oleic acid); C20:1 (gadoleic acid);

PUFA n3: polyunsaturated fatty acids n-3, C18:3 (pinolenic acid);

PUFA n-6: polyunsaturated fatty acids n-6, C18:2 (rumenic acid); C20:4 (arachidonic acid).

C: control; M: monensin $(25 \mathrm{~g} / \mathrm{t})$; A: adiCox®AP $(50 \mathrm{~g} / \mathrm{t})$.

SEM: standard error of mean.

The oxidative stability of the abdominal fat of the chickens was evaluated based on the TBARS index. Values of this index, achieved in the study, enable the conclusion that the addition of the ionophore coccidiostat to feed mixtures effected a lower rate of abdominal fat oxidation, which was indicated by lower TBARS index values both $72 \mathrm{~h}(0.475), 7$ days (1.250) and 8 weeks (0.743) after slaughter, compared with groups $\mathrm{C}$ and $\mathrm{M}$ (Table 7 ). 
Table 7 Effect of diets with or without coccidiostast on susceptibility of chicken abdominal fat to oxidation (TBARS index, mg MDA) during storage at $4{ }^{\circ} \mathrm{C}$ and $-18{ }^{\circ} \mathrm{C}$

\begin{tabular}{lccc}
\hline \multirow{2}{*}{ Group } & \multicolumn{3}{c}{ Storage time } \\
\cline { 2 - 4 } & $\mathbf{3}$ days at $\mathbf{4}^{\circ} \mathbf{C}$ & $\mathbf{7}$ days at $\mathbf{4}{ }^{\circ} \mathbf{C}$ & $\mathbf{5 6}$ days at $\mathbf{- 1 8} \mathbf{~}^{\circ} \mathbf{C}$ \\
\hline $\mathrm{C}$ & $1.08^{\mathrm{a}}$ & $2.43^{\mathrm{a}}$ & $1.76^{\mathrm{a}}$ \\
$\mathrm{M}$ & $0.48^{\mathrm{b}}$ & $1.33^{\mathrm{b}}$ & $0.74^{\mathrm{b}}$ \\
$\mathrm{A}$ & $0.52^{\mathrm{b}}$ & $1.25^{\mathrm{b}}$ & $1.19^{\mathrm{b}}$ \\
SEM & 0.07 & 0.06 & 0.07
\end{tabular}

Mean values in the same column with different superscripts $(a, b)$ differ significantly $(P \leq 0.05)$.

C: control; M: monensin (25 g/t); A: adiCox®AP (50 g/t).

\section{Discussion}

The addition of coccidiostats in Groups $\mathrm{A}$ and $\mathrm{M}$ had a significant effect on the mortality rate compared with the control group (Table 2). Results achieved in the study point to the possibility of applying natural plant extracts in feed mixtures as natural coccidiostats without reducing the production results of chickens. In the chickens from Group A (plant coccidiostat), an improvement was noticed in rearing effectiveness, which was indicated by a reduced mortality rate (2.6\%). These results confirm the findings of Gornowicz (2003), who demonstrated that groups of chickens fed feed mixtures without a growth stimulant and without herbs achieved worse rearing results than the group receiving a 1.5\% addition of herbs. The mixture of dry herbs contained marigold flowers, St John's Wort, marshmallow root, camomile flowers, peppermint, yarrow and nettle. These herbs had a positive effect on the values of the final production results of broiler chickens - the mortality rate decreased to $2.2 \%$. Bitter substances, terpenes and phenolic acids stimulate the production of digestive juices rich in endogenous enzymes, which could have contributed to the weight gains recorded in Group A.

The application of various coccidiostats to feed mixtures of chickens reared until 63 days of age had no significant effect on dressing percentage or on the contents of breast and leg muscles in carcasses. A study by Kinal et al. (1998) also proved no effect of herbal additive on dressing percentage.

Results of the assays of the proximate chemical composition of breast and leg muscles of the chickens are presented in Table 3. In a study by Gornowicz (2003), a 1\% addition of an herbal mixture to the diet showed that the chemical composition of breast and leg muscles was relatively similar, and no significant differences were demonstrated between the groups. The content of protein in breast muscles ranged from $22.5 \%$ to $23.9 \%$, and in leg muscles from $18.1 \%$ to $20.0 \%$. These values are similar to the results achieved in our study for breast muscles and slightly lower than these reported for leg muscles.

The technological value of meat, and thus indirectly of the quality of products made from it, is affected, among other things, by its $\mathrm{pH}$ and water-holding capacity. In the experiment, these parameters were assayed in breast and leg muscles of the chickens $24 \mathrm{~h}$ after slaughter (Table 5). No significant differences were demonstrated in the $\mathrm{pH}$ value of the muscles. The $\mathrm{pH}$ values recorded were similar to those reported by other authors who investigated the effect of plant additives on the physicochemical properties of meat, and demonstrated that the $\mathrm{pH}$ of breast muscles ranged from 5.5 to 5.7 and in leg muscles from 6.2 to 6.5 (Fiłonik \& Niemiec, 2002). The pH value of meat is linked to its water-holding capacity. A decrease in $\mathrm{pH}$ value is accompanied by a decreasing water-binding ability, whereas along with $\mathrm{pH}$ value increase, the water-holding capacity of muscle proteins increases as well (Poltowicz, 2000). The experiment demonstrated a significant effect of the type of coccidiostat on the water-holding capacity of leg muscles. Better waterholding capacity was reported for muscles of the chickens administered the feed mixture with the addition of plant coccidiostat (Table 4). In addition, the same group analyses demonstrated the lowest cooking loss in leg muscles. These values differed significantly $(P \leq 0.05)$ from those reported in the other groups, which could be owing to lower $\mathrm{pH}$ values.

In the experiment, significant $(P \leq 0.05)$ differences were observed in the contribution of fatty acids in intramuscular fat of breast muscles for saturated fatty acid (SFA) and monounsaturated fatty acid (MUFA) and in abdominal fat (SFA). The highest contribution of SFA was assayed in Group M, and these values were confirmed statistically (Table 6). The content of SFAs in a human diet determines the cholesterol level in the blood serum. One of the indicators of the health quality of a food product is the intake of polyunsaturated fatty acids (PUFAs) and the $n-6 / n-3$ fatty acids ratio, which, according to dieticians (Turley \& Strain, 1993), should be in the range of $4-6: 1$. According to the latest nutritional recommendations, 
saturated fatty acids should cover not more than $10 \%$ of daily energy demand. It is also recommended that the polyunsaturated fatty acids of the $n-6$ family should provide $4 \%-8 \%$ of the energy. In turn, among PUFAs of the $n-3$ family, the recommended daily dose is $2 \mathrm{~g}$ of $\alpha$-linolenic acid and $200 \mathrm{mg}$ of other long chain $n$-3 PUFAs. The remaining dose of energy originating from dietary fats should be provided in the form of MUFAs (Jarosz \& Buthak-Jachymczyk, 2008). Many investigations have been carried out in recent years that demonstrated that the $n-3$ fatty acids contributed to the inhibition of many chronic diseases. The increased supply of these acids may also reduce the incidence of many civilization diseases, for example ischemic heart disease (Engler \& Engler, 2006). Studies have also shown a relationship between $n-3$ fatty acid deficiency and other chronic disorders, such as hypertension, inflammatory states, disorders of neurological functions and depression (Logan, 2004). The high level of unsaturated fatty acids in poultry fat, however, may exert a negative effect on its stability.

Ongoing transformations in lipids during poultry meat storage in a frozen state proceed at a higher rate than in proteins and are the main cause of undesirable sensory and chemical changes of raw material (Grabowski, 1993). The oxidative stability of the abdominal fat of the chickens was evaluated based on the TBARS index during sample storage in refrigerated conditions and in the frozen state. The results are presented in Table 7. An increase in the TBA index points to oxidative changes occurring in fat. In the experiment, the addition of the ionophore coccidiostat to feed mixtures was observed to affect a lower rate of abdominal fat oxidation, which was indicated by lower values of the TBARS index assayed both $72 \mathrm{~h}(0.48)$ and 8 weeks (0.74) after slaughter, compared with Groups $C$ and $A$. The decreased rate of fat oxidation was also observed after seven days of slaughter in the groups of chickens receiving the plant coccidiostat (Table 7). All values were confirmed statistically. Results of a study by Pietrzak et al. (2002) confirmed the effect of a plant preparation added to a feed mixture for broiler chickens on the retardation of oxidative changes in abdominal fat of chickens during storage, both under refrigerated conditions and in a frozen state.

Currently, coccidiosis poses a severe health problem (Lunden et al., 2000; Parker et al., 2007). It effects deterioration of production results, increases susceptibility to diseases and, consequently, causes economic losses (Michalski, 2007). The administration of coccidiostats in feed is, so far, the cheapest and the most effective method of coccidiosis prophylaxis. The substitution of ionophore and chemical coccidiostats with a natural additive may contribute to the production of meat with better technological usability.

For many years studies have been conducted on the feasibility of applying herbal extracts with bactericidal and protozoacidal properties to poultry feeding. The extracts have also been demonstrated to exert positive effects on production results and final bodyweight of non-infected birds (Waldenstedt, 2003). For decades, herbs have been used not only in human and veterinary medicine, but as a component of feed doses in animal feeding. In recent years, much attention has been paid to the usability of herbs in poultry production owing to the universal and complex character of their action (Faruga et al., 2002; Gornowicz, 2003). Various herbs and their mixtures have been incorporated in feed mixtures for all animal species, poultry in particular (Faruga \& Puchajda, 2000; Faruga et al., 2003). Herbal materials may originate from field cultures (80\%) and from natural communities of wild plants (20\%). Currently, the interest in herbs has shifted from the plant material itself to active substances contained in it, their activity and mechanism of action. A number of studies have been conducted in recent years on the effects of, among others, sage, oregano, thyme and their phenols (Ibrir et al., 2001; Szaboova et al., 2008). Apart from the advantages (above), herbal extracts do not pose any risk of meat contamination with detrimental substances.

\section{Conclusion}

The administration of the plant feed supplement adiCox®AP had a significant effect on the mortality rate of broiler chickens, without compromising the other production effects. The results also show that the applied plant preparation is an excellent alternative to antibiotic growth stimulants because active substances of plant origin do not require a waiting period. Unlike ionophore coccidiostats, they may be applied during the entire rearing period, which simultaneously contributes to the improvement of health safety of meat and meat products. In particular, these additives will play a significant role in the maintenance of health status and welfare of chickens when consumers expect food products to be free from pharmacological preparations.

\section{Acknowledgements}

This study was carried out as part of research project no. NN311 405239 MNiSW in 2010-2012.

\section{References}

Abbas, R.Z., Iqbal, Z., Khan, M.N., Zafar, M.A. \& Zia, M.A., 2010. Anticoccidial activity of Curcuma longa L. in broilers. Braz. Arch. Biol. Technol. 52, 63-66. 
Anonymous, 2003. Regulation (EC) No $1831 / 2003$ of the European Parliament and of the Council of 22 September 2003 on additives for use in animal nutrition. Off. J. Europ. Union, L 268, 29-43.

AOAC, 1995. Official Methods of Analysis. Association of Official Analytical Chemists. Arlington, V.A., USA.

Chandrakesan, P., Muralidharan, K., Kumar, V.D., Ponnudurai, G., Harikrishnan, T.J. \& Rani, K.S.V.N., 2009. Efficacy of a herbal complex against caecal coccidiosis in broiler chickens. Vet. Arh. 79, 199-203.

Engler, M.M. \& Ebgler, M.B., 2006. Omega-3 fatty acids: role in cardiovascular health and disease. J. Cardiovasc. Nurs. 1 (1), 17-24.

Faruga, A. \& Puchajda, H., 2000. The effectiveness of rearing turkeys fed with herbal ingredients Biostrong 500. Zesz. Nauk. Prz. Hod., PTZ, 49, 297-304. (in Polish).

Faruga, A., Pudyszak, K., Koncicki, A. \& Polak, M., 2002. Effects of herbal Biostrong 500 for raising the efficiency and level of some blood biochemical indices turkeys for fattening. Med. Wet. 58 (10), 796-798. (in Polish).

Faruga, A., Polak, M., Jędryczko, R. \& Łowczak, I., 2003. Wyniki odchowu i aktywność enzymów surowicy krwi indyków żywionych mieszankami z zawartością flawomycyny lub preparatu ziołowego. Biul. Nauk. 22, 167-171. (in Polish).

Fiłonik, A. \& Niemiec, J., 2002. Influence of growth stimulants on performance, level of lipids and physicochemical properties of broiler meat]. Rocz. Nauk. Zoot., Supl., z. 16, 305-310 (in Polish).

Gornowicz, E., 2003. Production of safe food for health based on indigenous breeds of poultry. Zakrzewo, 71-80. (in Polish).

Grabowski, T., 1993. Poultry Technology. WNT, Warszawa. (in Polish).

Haq, I., Pasha, T. \& Khalique, A., 2011. Comparative efficacy of herbal and allopathy drugs against coccidiosis in poultry. Ital. J. Anim. Sci. 10, 14-16.

Ibrir, F., Greathead, H.M.R. \& Forbes, J.M., 2001. The effect of thymol/carvacrol treatments on the performance of broiler chickens infected with Eimeria acervulina. In: Proceedings of AFAC Workshop 'Alternatives to Feed Antibiotics and Anticoccidials in the Pig and Poultry Meat Production', pp. 1-2. (http://www2.slu.se/Workshop20Norge/Poster \%20abstract2F\%20brir.pdf).

Jarosz, M. \& Bułhak-Jachymczyk, B., 2008. Standards of human nutrition. Fundamentals of prevention of obesity and non-communicable diseases. Wydawnictwo Lekarskie PZWL, Warszawa. (in Polish).

Kennedy, D.G., Blanchflower, W.J. \& O'dornan, B.C., 1995. Development of an ELISA for lasalocid and depletion kinetics of lasalocid residues in poultry. Food Addit. Contam. 12, 83-92.

Kinal, S., Schleicher, A. \& Fritz, Z., 1998. The use of some herbs in concentrates for broiler chickens. Zeszyty Nauk. AR Wrocław, Zoot. XLIV. 350, 69-77. (in Polish).

Lee, S.H., Lillehoj, H.S., Jang, S.I., Kim, D.K., Ionescu, C. \& Bravo, D., 2010. Effect of dietary Curcuma, Capsicum, and Lentinus on enhancing local immunity against Eimeria acervulina infection. J. Poult. Sci. 47, 87-85.

Logan, A.C., 2004. Omega-3 fatty acids and major depression: A primer for the mental health professional. Lipids Health Dis. 9 (3), p. 25.

Lunden, A., Thebo, P., Gunnarsson, S., Hooshmand-Rad, P., Tauson, R. \& Uggla, A., 2000. Eimeria infections in litter-based, high stocking density systems for loose-housed laying hens in Sweden. Br. Poult. Sci. 41, 440-447.

Michalski, M. 2007. Economic losses caused by parasite invasions in animals and methods of their evaluation. Vet. Med. 63 (6), 643-647.

Mitek, M. \& Słowiński, M., 2006. Selected aspects of food technology. SGGW. (in Polish).

Olejnik, M. \& Szprengier-Juszkiewicz, T., 2007. Coccidiostats residues in poultry tissues and eggs. Vet. Med. 63 (12), 1539-1545.

Olejnik, M., Szprengier-Juszkiewicz, T. \& Żmudzki, J., 2009. New legislation for coccidiostats in food of animal origin and feedstuffs. Vet. Med. 65, 807-811.

Parker, J., Oviedo-Rondón, E.O., Clack, B.A., Clemente-Hernández, S., Osborne, J., Remus, J.C., Ketunen, H., Mäkivuokko, H. \& Pierson, E.M., 2007. Enzymes as feed meal diets with differentprotein levels. Poult. Sci. 86, 643-653.

Peisker, K., 1964. A rapid semi-micro method for preparation of methyl esters from triglycerides using chloroform, methanol, sulphuric acid. J. Am. Oil Chem. Soc. 11, 87-90.

Pelicia, K., Mendes, A.A., Saldanha, E.S.P.B., Pizzolante, C.C., Takahashi, S.E., Garcia, R.G., Moreira, J., Paz, I.C.L.A., Quinteiro, R.R. \& Komiyama, C.M., 2004. Probiotic and prebiotic utilization in diets for free-range broiler chickens. Braz. J. Poult. Sci. 6 (2), 99-104.

Polish Standard PN-ISO 5509, 1996. Animal and vegetable fats and oils - Preparation of methyl esters of fatty acids. (in Polish). 
Połtowicz, K., 2000. Effect of initial pH level pectoral muscles on selected indicators meat quality of broiler chickens belonging to the three genotypes. Rocz. Nauk. Zoot. Supl. 8, 161-165. (in Polish).

Ruff, M.D. \& Danforth, H.D., 1996. Resistance of coccidian to medications. Proc. XX Worlds Poultry Congress. II, 427-430.

Russell, J.B., 1987. A proposed mechanism of monensin action in inhibiting ruminal bacterial growth: effects on ion flux and protonmotive force. J. Anim. Sci. 64, 1519-1525.

Różański, H. \& Drymel, W., 2010. AdiCox jako źródło fitoaleksyn i fitoncydów. Pol. Drob. 12, 17-20. (in Polish).

Shahidi, F., 1990. The 2-thiobarbituric acid (TBA) methodology for the evaluation of warmed - over flavour and rancidity in meat products. Proc. 36th ICoMST, Havana, 1008.

Szaboova, R., Laukova, A., Chrastinova, L., Simonova, M., Strompfova, V., Haviarova, M., Placha, I., Faix, S., Vasilkova, Z., Chrenkova, M. \& Rafay, J., 2008. Experimental application of sage in rabbit husbandry. Acta Vet. Brno 77, 581-588.

Turley, E. \& Strain J.J., 1993. Fish oil, eicosanoid biosynthesis and cardiovascular disease, an overview. Int. J. Food Sci. Nutr., 2,145.

Waldenstedt, L., 2003. Effect of vaccination against coccidiosis in combination with an antibacterial oregano (Oreganum vulgare) compound in organic broiler production. Acta Agr. Scand., Sect. A. Anim. Sci. 53, 101-109.

Wierbicki, E., Tiede, M.G. \& Burrell, R.G., 1962. Die Bestimmung der Fleischquellung als Methode zur Untersuchung der Wasserbindungskapazität von Muskelprotein mit geringen Safthaltvermögen. Fleischwirtschaft 14, 948-951. (in German). 